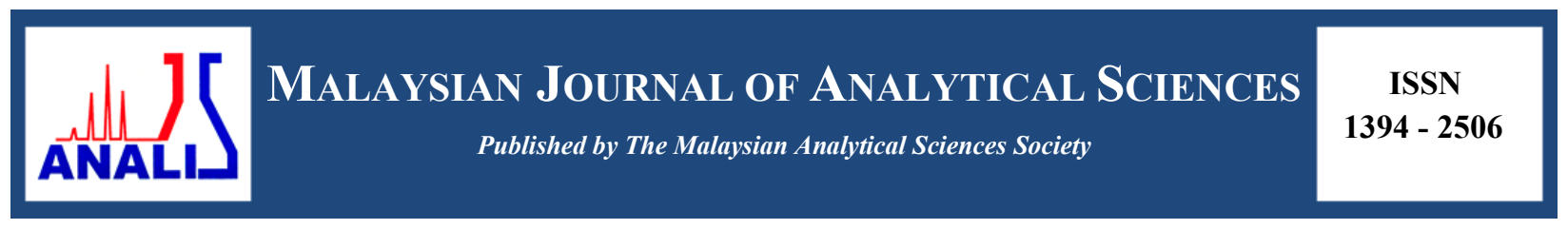

\title{
ISOLATION OF FOUR STEROIDS FROM THE LEAVES OF FERN Adiantum latifolium Lam
}

\author{
(Pengasingan Empat Steroid Daripada Daun Paku Pakis Adiantum latifolium Lam) \\ Andi Rifki Rosandy ${ }^{1}$, Nurnida Mohd. Kamal ${ }^{2}$, Noraini Talip ${ }^{2}$, Rozida Khalid ${ }^{1}$, Muntaz Abu Bakar ${ }^{1 *}$ \\ ${ }^{I}$ School of Chemical Sciences and Food Technology, Faculty of Science and Technology \\ ${ }^{2}$ School of Environmental and Natural Resources Sciences, Faculty of Science and Technology \\ Universiti Kebangsaan Malaysia, 43650 UKM Bangi, Selangor, Malaysia \\ *Corresponding author: muntaz@ukm.edu.my
}

Received: 1 August 2016; Accepted: 27 February 2017

\begin{abstract}
Isolation of compounds from methanol extract from the leaves of Adiantum latifolium Lam. had been conducted by using radial chromatography and thin layer chromatography (TLC) techniques. Their structures were elucidated by ultraviolet-visible (UV), infrared (IR), nuclear magnetic resonance (NMR) and mass spectroscopy (MS) and by comparison with the previous literatures. Four steroids compound were isolated namely the Stigmast-4-en-3-one (1), Stigmasta-4,22-dien-3-on (2), Stigmasterol (3) and $\beta$ Sitosterol (4).
\end{abstract}

Keywords: Adiantum latifolium, adiantaceae, steroid

\begin{abstract}
Abstrak
Pengasingan sebatian daripada ekstrak metanol daripada daun Adiantum latifolium Lam. telah dilakukan dengan menggunakan teknik kromatografi pepejal dan teknik kromatografi lapisan nipis (TLC). Struktur semua sebatian dicirikan dengan menggunakan ultra lembayung (UV), inframerah (IR), resonans magnet nukleus (NMR) dan spektroskopi jisim (MS), dan secara perbandingan dengan data kepustakaan. Empat sebatian steroid telah diasingkan iaitu, Stigmasta-4-en-3-on (1), Stigmasta-4,22dien-3-on (2), Stigmasterol (3) and $\beta$-Sitosterol (4).
\end{abstract}

Kata kunci: Adiantum latifolium, adiantaceae, steroid

\section{Introduction}

Adiantum is a genus belonging to the Adiantaceae family that consists of nearly 150 species and are widely distributed all over the world [1]. This species is indigenous to the central of America and northern South America and known as the common weed species in plantation [2]. It was introduced into Malaysia and became naturalized especially in palm plantation as weed. Adiantum is known in different names between countries. In some countries, this species is known as Maidenhair fern (English), Hansraj (India) and Tie Xian Jue Shu (China). Traditionally, most of the Adiantum species are used for treatments of chest complaints, cough, increase of lactation, colds, aidkidney function, antiphrastic and to treat dandruff [3]. In Chinese medicinal practice, they also use Adiantum species to cure human and animal diseases including relief of internal heat or fever, enhancement of urination, removal of urinary calculus, relief of cough, cure of diarrhea and bleeding stoppage [4]. Concerning the phytochemical studies, most of Adiantum species have produced sterols [5, 6], any classes of flavonoid triterpenoids $[7,8,9]$ and any classes of triterpenoids [10]. According to Nonato et al., Adiantum latifolium Lam can be used to 
treat anxiolytic and analgesic [11]. So far, the chemical structures from Adiantum latifolium Lam have not reported. The main objective of this paper is to describe the isolation and structure characterization from the frond part of Adiantum latifolium Lam.

\section{Plant materials}

\section{Materials and Methods}

In July 2014, the leaves part of Adiantum latifolium Lam were collected from Tasik Chini Research Center, Pahang, Malaysia. Herbarium specimen of NMK091 was deposited at the Universiti Kebangsaan Malaysia Herbarium (UKMB).

\section{Extraction and isolation}

Dried ground of the leaves of Adiantum latifolium Lam (120 g) was macerated with methanol at room temperature. The filtrate was concentrated using a rotary evaporator to yield a dark green extract (4 g, 4\%). A 3-g portion of the extract was fractionated by using radial chromatography (RC) with $4 \mathrm{~mm}$ thickness silica gel on a round glass plate eluted with increasing polarity of $n$-hexane-EtOAc. The eluents that showed the same profile on thin layer chromatography (TLC) chromatogram were combined to give three fractions (I-III). Purification of fraction I (600 $\mathrm{mg}$ ) was carried out using RC with a silica gel plate of $1 \mathrm{~mm}$ thickness eluted with 95:5 $n$-hexane-EtOAc in 5\% polarity increment to yield compounds 1 (3 mg). Purification of fraction II (410 $\mathrm{mg})$ was conducted, utilizing another RC with silica gel plate of $1 \mathrm{~mm}$ thickness. Elution with 9:1 $n$-hexane-EtOAc produced compound 2 (5 mg) and $3(20 \mathrm{mg})$. Purification of fraction III $(430 \mathrm{mg})$ was then performed using RC with the silica gel plate of $1 \mathrm{~mm}$. Elution with 7:2:1 $n$-hexane-EtOAc- $\mathrm{CHCl}_{3}$ resulted in compound $4(8 \mathrm{mg})$.

\section{Compound identification}

Structure elucidation of pure compound was determined based on the spectral data recorded on Shimadzu UV-260 spectrophotometer, Frontier Perkin-Elmer FTIR/NIR spectrophotometer and Bruker NMR $700 \mathrm{MHz}$ Cryo-Probe instrument that included 1-D and 2-D NMR. Mass of compounds was recorded by using LCMS-Ultra Performance Liquid Chromatography (UPLC), Brand Waters. The isolation was then carried out by radial chromatography using round glass plates of the Merck Kieselgel 60 PF254 (art. no. 7749) and the profile was analyzed using smaller pieces from aluminum sheets of $20 \times 20 \mathrm{~cm}$ of the Merck TLC silica gel 60 F254 of 0.25 mm thickness (art. no. $5554)$ and then detected under UV light (254 $\mathrm{nm}$ ) or by a $\mathrm{CeSO}_{4}$ spraying reagent test.

Stigmast-4-en-3-one (1)

\section{Results and Discussion}

White crystal; m.p: $82-84^{\circ} \mathrm{C}$. ESI-MS $m / z 413[\mathrm{M}+\mathrm{H}]^{+}$(calc. for $\mathrm{C}_{29} \mathrm{H}_{49} \mathrm{O}$ ). UV (MeOH) $\lambda_{\max }$ : $241 \mathrm{~nm}$. IR $v_{\max }$ (ATR) $\mathrm{cm}^{-1}$ : 2926-2868 (Csp $\left.{ }^{3}-\mathrm{H}\right), 1708(-\mathrm{C}=\mathrm{O}), 1678-1414$ (-C=C-), 1243-1125 (C-O), $969\left(-\mathrm{CH}_{3}\right) .{ }^{1} \mathrm{H}_{-} \mathrm{NMR}(700$ $\left.\mathrm{MHz}, \mathrm{CDCl}_{3}\right)$ and ${ }^{13} \mathrm{C}-\mathrm{NMR}\left(175 \mathrm{MHz}, \mathrm{CDCl}_{3}\right)$ are tabulated in Table 1.

\section{Stigmasta-4, 22-dien-3-on (2)}

Colorless crystal; m.p: $80-82^{\circ} \mathrm{C}$. ESI-MS $m / z 411.3627[\mathrm{M}+\mathrm{H}]^{+}$(calcd for $\left.\mathrm{C}_{29} \mathrm{H}_{47} \mathrm{O}\right)$. IR $v_{\max }(\mathrm{ATR}) \mathrm{cm}^{-1}: 2929-2867$ $\left(\mathrm{Csp}^{3}-\mathrm{H}\right), 1708(-\mathrm{C}=\mathrm{O}), 1453(-\mathrm{C}=\mathrm{C}-), 1376-1307(-\mathrm{C}-\mathrm{O}), 958-907\left(-\mathrm{CH}_{3}\right) .{ }^{1} \mathrm{H}-\mathrm{NMR}\left(700 \mathrm{MHz} \mathrm{CDCl}_{3}\right)$ and ${ }^{13} \mathrm{C}-$ $\operatorname{NMR}\left(175 \mathrm{MHz}, \mathrm{CDCl}_{3}\right)$ are tabulated in Table 1.

\section{Stigmasterol (3)}

Colorless crystal; m.p: $168-170^{\circ} \mathrm{C}$. ESI-MS $m / z 413[\mathrm{M}+\mathrm{H}]^{+}$(calcd for $\left.\mathrm{C}_{29} \mathrm{H}_{49} \mathrm{O}\right)$. IR $v_{\max }(\mathrm{ATR}) \mathrm{cm}^{-1}: 3423(b r-$ $\mathrm{OH}), 2936\left(\mathrm{Csp}^{3}-\mathrm{H}\right), 1642-1449(\mathrm{C}=\mathrm{C}), 1112(\mathrm{C}-\mathrm{OH}), 910\left(-\mathrm{CH}_{3}\right) .{ }^{1} \mathrm{H}-\mathrm{NMR}\left(700 \mathrm{MHz}, \mathrm{CDCl}_{3}\right)$ and ${ }^{13} \mathrm{C}-\mathrm{NMR}(175$ $\left.\mathrm{MHz}, \mathrm{CDCl}_{3}\right)$ is tabulated in Table 1 .

\section{$\beta$-Sitosterol (4)}

Colorless crystal; m.p: $144-146^{\circ} \mathrm{C}$. ESI-MS m/z $415[\mathrm{M}+\mathrm{H}]^{+}$(calcd for $\left.\mathrm{C}_{29} \mathrm{H}_{51} \mathrm{O}\right)$. IR $v_{\max }(\mathrm{ATR}) \mathrm{cm}^{-1}: 3346(b r-$ $\mathrm{OH}), 2987-2831\left(\mathrm{Csp}^{3}-\mathrm{H}\right), 1449(-\mathrm{C}=\mathrm{C}-), 1022(\mathrm{C}-\mathrm{OH}), 910\left(-\mathrm{CH}_{3}\right) .{ }^{1} \mathrm{H}-\mathrm{NMR}\left(700 \mathrm{MHz}, \mathrm{CDCl}_{3}\right)$ and ${ }^{13} \mathrm{C}-\mathrm{NMR}$ $\left(175 \mathrm{MHz}, \mathrm{CDCl}_{3}\right)$ is tabulated in Table 1 . 
Table 1. NMR data (APT and ${ }^{1} \mathrm{H}$ NMR) of compound 1-4

\begin{tabular}{|c|c|c|c|c|c|c|c|c|}
\hline \multirow{2}{*}{ No } & \multicolumn{4}{|c|}{ APT (ppm) } & \multicolumn{4}{|c|}{${ }^{1} \mathrm{H}($ mult.,$J$ in $\left.\mathrm{Hz}, \Sigma H)\right)$} \\
\hline & 1 & 2 & 3 & 4 & 1 & 2 & 3 & 4 \\
\hline 1 & 35.7 & 35.7 & 37.2 & 37.2 & & & & \\
\hline 2 & 33.9 & 33.8 & 32.0 & 32.0 & & & & \\
\hline 3 & 199.7 & 199.7 & 71.8 & 71.8 & - & - & $3.51(m ; 1 \mathrm{H})$ & $3.51(m ; 1 \mathrm{H})$ \\
\hline 4 & 123.7 & 123.7 & 42.2 & 42.2 & $5.74(s ; 1 \mathrm{H})$ & $5.74(s ; 1 \mathrm{H})$ & & \\
\hline 5 & 171.8 & 171.8 & 140.7 & 140.7 & - & - & - & - \\
\hline 6 & 33.0 & 33.0 & 121.7 & 121.7 & & & $\begin{array}{c}5.34 \\
(t, J=5.4 ; 1 \mathrm{H})\end{array}$ & \\
\hline 7 & 32.0 & 32.0 & 31.6 & 31.6 & & & & \\
\hline 8 & 36.1 & 35.6 & 31.9 & 31.9 & & & & \\
\hline 9 & 53.8 & 55.9 & 50.1 & 50.1 & & & & \\
\hline 10 & 38.6 & 38.6 & 36.5 & 36.5 & - & - & - & - \\
\hline 11 & 21.0 & 21.0 & 21.0 & 21.0 & & & & \\
\hline 12 & 39.6 & 39.6 & 39.7 & 39.7 & & & & \\
\hline 13 & 42.3 & 42.4 & 42.3 & 42.3 & - & - & - & - \\
\hline 14 & 55.9 & 53.8 & 56.7 & 56.7 & & & & \\
\hline 15 & 24.2 & 24.2 & 26.0 & 26.0 & & & & \\
\hline 16 & 28.8 & 28.9 & 28.9 & 28.9 & & & & \\
\hline 17 & 56.0 & 56.0 & 56.0 & 56.0 & & & & \\
\hline 18 & 12.0 & 11.9 & 11.8 & 11.8 & $0.72(s ; 3 \mathrm{H})$ & $0.75(s ; 3 \mathrm{H})$ & $0.68(s ; 3 \mathrm{H})$ & $0.73(s ; 3 \mathrm{H})$ \\
\hline 19 & 17.4 & 17.4 & 19.0 & 19.0 & $1.19(s ; 3 \mathrm{H})$ & $1.20(s ; 3 \mathrm{H})$ & $0.99(s ; 3 \mathrm{H})$ & $1.18(s ; 3 \mathrm{H})$ \\
\hline 20 & 36.1 & 40.5 & 40.5 & 40.5 & & & & \\
\hline 21 & 21.2 & 21.2 & 18.7 & 18.7 & $\begin{array}{c}0.93 \\
(d, J=6.6 ; 3 \mathrm{H})\end{array}$ & $\begin{array}{c}1.03 \\
(d, J=6.6 ; 3 \mathrm{H})\end{array}$ & $\begin{array}{c}0.91 \\
(d, J=6.3 ; 3 \mathrm{H})\end{array}$ & $\begin{array}{c}1.02 \\
(d, J=7.5 ; 3 \mathrm{H})\end{array}$ \\
\hline 22 & 34.0 & 138.1 & 138.3 & 33.95 & & $\begin{array}{c}5.15 \\
\left(d d, J_{l}=15.1\right. \\
\left.J_{2}=8.7 ; 1 \mathrm{H}\right)\end{array}$ & $\begin{array}{c}4.99 \\
\left(d d, J_{I}=9.0\right. \\
\left.J_{2}=15.5 ; 1 \mathrm{H}\right) \\
1 \mathrm{H}\end{array}$ & \\
\hline 23 & 26.1 & 129.4 & 129.2 & 26.10 & & $\begin{array}{c}5.04 \\
\left(d d, J_{1}=15.1, J_{2}\right. \\
\quad=8.7 ; 1 \mathrm{H})\end{array}$ & $\begin{array}{c}5.14 \\
\left(d d, J_{I}=9.0\right. \\
\left.J_{2}=15.5 ; 1 \mathrm{H}\right)\end{array}$ & \\
\hline 24 & 51.2 & 51.2 & 51.2 & 51.2 & & & & \\
\hline 25 & 29.1 & 32.0 & 29.1 & 29.1 & & & & \\
\hline 26 & 19.8 & 19.0 & 19.8 & 19.8 & $\begin{array}{c}0.84 \\
(d, J=6.8 ; 3 \mathrm{H})\end{array}$ & $\begin{array}{c}0.86 \\
(d, J=6.4 ; 3 \mathrm{H})\end{array}$ & $\begin{array}{c}0.81 \mathrm{~d} \\
(d, J=6.5 ; 3 \mathrm{H})\end{array}$ & $\begin{array}{c}0.80 \\
(d, J=6.0 ; 3 \mathrm{H})\end{array}$ \\
\hline 27 & 19.0 & 21.1 & 19.4 & 19.4 & $\begin{array}{c}0.82 \\
(d, J=6.8 ; 3 \mathrm{H})\end{array}$ & $\begin{array}{c}0.86 \\
(d, J=6.4 ; 3 \mathrm{H})\end{array}$ & $\begin{array}{c}0.76 \\
(d, J=6.5 ; 3 \mathrm{H})\end{array}$ & $\begin{array}{c}0.85 \\
(d, J=6.0 ; 3 \mathrm{H})\end{array}$ \\
\hline 28 & 23.0 & 25.4 & 23.0 & 23.0 & & & & \\
\hline 29 & 11.9 & 12.0 & 11.9 & 11.9 & $\begin{array}{c}0.85 \\
(t, J=7.2 ; 3 \mathrm{H})\end{array}$ & $\begin{array}{c}0.82 \\
(t, J=7.3 ; 3 \mathrm{H})\end{array}$ & $\begin{array}{c}0.84 \mathrm{t} \\
(t, J=3.3 ; 3 \mathrm{H})\end{array}$ & $\begin{array}{c}0.81 \\
(m ; 3 \mathrm{H})\end{array}$ \\
\hline
\end{tabular}

*APT (experiment for $\left.{ }^{13} \mathrm{C} \mathrm{NMR}\right)$. 
Four steroid compounds were successfully isolated from the methanol extract of the frond part of A. latifolium. The known compounds were elucidated based on the FTIR, MS and NMR $\left({ }^{1} \mathrm{H}\right.$ and $\left.{ }^{13} \mathrm{C}\right)$ techniques and by comparison of physical and spectroscopic data with values found in the literature. Table 1 displays ${ }^{1} \mathrm{H}$ and ${ }^{13} \mathrm{C}$ NMR data of the isolated compounds. Stigmast-4-en-3-one (1) was isolated as a white amorphous. FT-IR (ATR) $v_{\max } \mathrm{cm}^{-1}: 2926-2868$ (cyclic aliphatic), $1731(-\mathrm{C}=\mathrm{O})$ and 1647-1459 $(-\mathrm{C}=\mathrm{C}-)$. The mass spectrum showed a molecular ion peak ESI-MS $[\mathrm{M}]^{+}$at $m / z 412$ which was analyzed for the molecular formula $\mathrm{C}_{29} \mathrm{H}_{48} \mathrm{O}$. The ${ }^{13} \mathrm{C}-\mathrm{NMR}$ data showed the presence of 29 carbon signals representing six methyl carbons at $\delta_{C}$ of 11.9, 12.0, 17.4, 19.0, 19.8 and $21.2 \mathrm{ppm}$; eleven methylene carbons at $\delta_{\mathrm{C}}$ of $35.7,33.9,33.0,32.0,21.0,39.6,24.2,28.8,34.0,26.1$ and $23.0 \mathrm{ppm}$; eight methine carbons at $\delta_{\mathrm{C}}$ of $123.7,36.1,53.8,55.9,56.0,36.1,51.2$ and $29.1 \mathrm{ppm}$; and four quaternary carbons at $\delta_{\mathrm{C}}$ of 199.7, $171.8,38.6$, and $42.3 \mathrm{ppm}$. Based on the data, compound $1 \mathrm{can}$ be assigned as a cyclic aliphatic triterpenoid where a double bond is formed between $\mathrm{C}-4$ and C-5, while carbonyl is formed at C-3. Meanwhile, a total of 46 protons appeared in the ${ }^{1} \mathrm{H}-\mathrm{NMR}$ spectrum as shown in Table 1 . Two singlet methyls bound directly to the rings, $\delta_{\mathrm{H}} 0.75$ $(\mathrm{H}-18)$ and $1.20(\mathrm{H}-19)$. Three doublet methyls at $\delta_{\mathrm{H}} 1.03(\mathrm{H}-21), 0.86(\mathrm{H}-26)$ and $0.86(\mathrm{H}-27)$, and one triplet methyl at $\delta_{\mathrm{H}} 0.82(\mathrm{H}-29)$ are located at the side chain outside the rings of the main skeleton. The occurrence of one highly-deshielded proton at $\delta_{\mathrm{H}} 5.74(\mathrm{H}-4)$ indicated the presence of one pair of double bond. The typical signal for the olefinic H-6 of the steroidal skeleton was evident from a proton at $\delta_{\mathrm{C}} 5.74$, integrating for one-proton.

Stigmasta-4,22-dien-3-on (2) is a white amorphous with m.p. 80-82 ${ }^{\circ} \mathrm{C}$. Its IR spectrum showed $v_{\max }$ absorption peaks at 2929-2867 $\left(\mathrm{Csp}^{3}-\mathrm{H}\right), 1708(-\mathrm{C}=\mathrm{O}), 1453(-\mathrm{C}=\mathrm{C}-), 1376-1307(-\mathrm{C}-\mathrm{O})$ and 958-907 $\left(-\mathrm{CH}_{3}\right)$. Compound 2 gave positive responses to the Liebermann-Burchard spray reagent, which indicated the presence of a triterpenoid nucleus. This assumption was reinforced by the ${ }^{13} \mathrm{C}-\mathrm{NMR}$ data that indicated the presence of 29 carbons as tabulated in Table 1 which included three olefinic carbon signals at $\delta_{\mathrm{C}} 123.7$ (C-4), $138.1(\mathrm{C}-22)$ and $129.4(\mathrm{C}-23)$ and one carbonyl at $\delta c 199.7$ (C-3). The ${ }^{1} \mathrm{H}-\mathrm{NMR}$ spectra showed the presence of 46 protons. Compound $\mathbf{2}$ had very similar NMR data with those of compound 1 except for the presence of two olefinic protons instead of two methylenes. Two olefinic protons were determined to be H-22 and H-23 based on its HMBC spectrum. Consequently, a molecular ion peak $[\mathrm{M}+\mathrm{H}]^{+}$at $\mathrm{m} / z 411$ was exhibited in its mass spectrum data, which gave a possible molecular formula of $\mathrm{C}_{29} \mathrm{H}_{47} \mathrm{O}$. The combined spectral data of ${ }^{13} \mathrm{C}$ NMR suggested that the triterpenoid was stigmasta-4.22-dien-3-on, which was further supported by comparison with the literature as tabulated in Table 1.

Stigmasterol (3) was obtained as colourless needle crystals. The mass spectral data indicated the molecular formula of this compound to be $\mathrm{C}_{29} \mathrm{H}_{48} \mathrm{O}$ with $\mathrm{m} / z$ of 412 . The FTIR spectral data showed a broad absorbance peak at 3423 $\mathrm{cm}^{-1}$, illustrating the stretching vibration of $\mathrm{O}-\mathrm{H}$ bond, and the peak at $1112 \mathrm{~cm}^{-1}$ indicated the vibration band of C$\mathrm{O}$ bend. The peak of Csp $p^{3}-\mathrm{H}$ stretch appeared at $2936 \mathrm{~cm}^{-1}$. An absorbance peak of symmetrical C=C stretching at $1642 \mathrm{~cm}^{-1}$ indicated the existence of olefinic group in this compound. The ${ }^{1} \mathrm{H}$ NMR experiment of (3) displays information of the presence of two singlet methyls bound directly to the rings, $\delta_{\mathrm{H}} 0.68(\mathrm{H}-18)$ and $0.99(\mathrm{H}-19)$. Three doublet methyls at $\delta_{\mathrm{H}} 0.91(\mathrm{H}-21), 0.81(\mathrm{H}-26)$ and $0.79(\mathrm{H}-27)$, and one triplet methyl at $\delta_{\mathrm{H}} 0.84(\mathrm{H}-29)$ are located at the side chain outside the rings of the main skeleton. A proton at $\delta_{\mathrm{H}} 3.51(\mathrm{H}-3)$ is attached to the oxygenbinding carbon (C-3). The occurrence of three highly-deshielded protons at $\delta_{\mathrm{H}} 5.34(\mathrm{H}-6), 4.99(\mathrm{H}-22)$, and $5.14(\mathrm{H}-$ 23) indicated the presence of two pairs of double bond. The typical signal for the olefinic H-6 of the steroidal skeleton was evident from a proton at $\delta_{\mathrm{C}} 5.34$ integrating for one-proton. The other olefinic protons, $\mathrm{H}-22$ and $\mathrm{H}-23$, are neighbours and are in trans position as indicated by their large coupling constants $(J=15.2)$. The APT experiment showed that this compound contained 29 carbons consisting of 6 methyls, 9 methylenes, 11 methines, and 3 quarternary carbons. A methine carbon at $\delta_{\mathrm{C}} 71.5(\mathrm{C}-3)$ indicated a carbon attached to an oxygen atom (oxymethine) which revealed the existence of a hydroxyl group. The presence of two double bonds in the molecule was confirmed by two pairs of highly deshielded carbons at $\delta_{\mathrm{C}} 140.7$ (C-5), 121.7 (C-6), 138.3 (C-22), and 129.2 (C-23). The DBE (Double Bond Equivalent) value is six, which means that this compound is a tetracyclic compound containing two double bonds. Therefore, compound $\mathbf{3}$ is identified as stigmasterol.

$\beta$-Sitosterol (4) was obtained in the form of colorless needle crystals. The mass spectrum showed a molecular ion peak EI-MS $[\mathrm{M}+\mathrm{H}]^{+}$at $\mathrm{m} / z 212$ which was analyzed for the molecular formula $\mathrm{C}_{29} \mathrm{H}_{51} \mathrm{O}$. Compound 4 also identified as steroid with a DBE value of five, one for a double bond and the other three as a tetracyclic chain. The differences between compound $\mathbf{3}$ and $\mathbf{4}$ lay on C-22 and C-23, where compound $\mathbf{4}$ had a double bond (Figure 1). 
<smiles>[Z6]C(CC)C(C)C(C)[C@H](C)[C@H]1CCC2C3CCC4=CC(=O)CC[C@]4(C)C3CC[C@]21C</smiles>

1

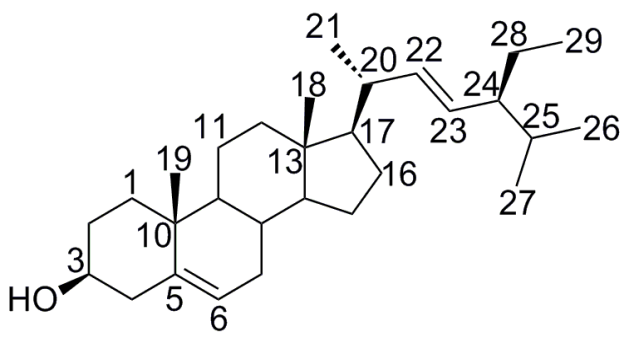

3

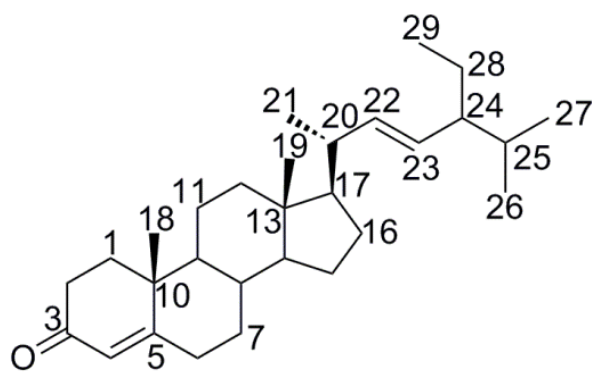

2

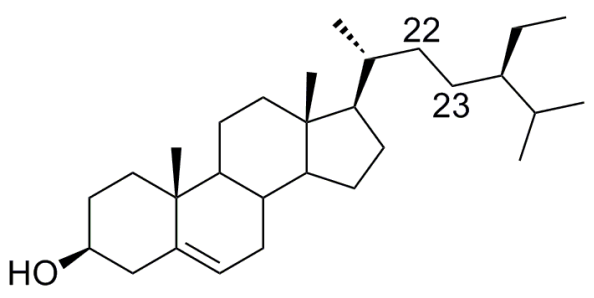

4

Figure 1. Chemical structures of 1, 2, 3 and 4

\section{Conclusion}

Four steroids namely Stigmast-4-en-3-one (1), stigmasta-4,22-dien-3-on (2), Stigmasterol (3) and $\beta$-Sitosterol (4) were successfully isolated from the leaves of Adiantum latifolium Lam. This is the first reported phytochemical study from this plant.

\section{Acknowledgement}

We would like to thank the School of Environmental and Natural Resources Science and the School of Chemical Science and Food Technology, Faculty of Science and Technology, Universiti Kebangsaan Malaysia (UKM); for providing research facilities and also would also like to express our gratitude to the Ministry of Higher Education Malaysia and UKM for the financial support through research grants of Regenerations of co-dominant plant family in Tasik Chini (DPP-2015-144), FRGS-1-2014-SG01-UKM-02-5 and Indonesia Endowment Fund for Education (LPDP).

\section{References}

1. Boonkerd, T. and Pollawatn, R. (2011). Adiantum capillus-junonis Rupr.: An additional species of Adiantum L. (Pteridaceae) for Thailand. Science Asia, 37: 370 - 372.

2. Piggott, A. G. (1988). Ferns of Malaysia in colour. Malaysia, Kuala Lumpur, Tropical Press. pp $420-421$.

3. Rajurkar, N. S. and Gaikwad, K. (2012). Evaluation of phytochemicals, antioxidant activity and elemental content of Adiantum capillus veneris leaves. Journal of Chemical and Pharmaceutical Research, 4(1): 365 374.

4. Pan, C., Chen, Y. G., Ma, X. Y., Jiang, J. H., He, F. and Zhang, Y. (2011). Phytochemical constituents and pharmacological activities of plants from the genus Adiantum: A review. Tropical Journal of Pharmaceutical Research, 10(5): $681-692$.

5. Guarrera, P. M., Lucchese, F. and Medori, S. (2008). Ethnophytotherapeutical research in high molise region (Central-Southern Italy). Journal of Ethnobiology and Ethnomedicine, 4: 1 - 11.

6. Marino, A., Elberti, M. G. and Cataldo, A. (1989). Phytochemical investigations of Adiantum capillus-veneris. Journal of Biological Research Bollettino Della Societaltaliana Di Biologia Sperimentale. 65: 461 - 463. 
7. Imperato, F. (1982). Kaempferol 3-sulphate in the fern Adiantum capillus-verenis. Phytochemistry, 21: 2158 2159.

8. Imperato, F. (1982). A new acylated flavonol glucoside from the fern Adiantum capillus-verenis L. Journal of Chemistry and Industry, 16: 604.

9. Pourmorad, F., Hosseinimehr, S. J. and Shahablmajd, N. (2006). Antioxidant activity, phenol and flavonoid contents of some selected Iranian medicinal plants. African Journal of Biotechnology, 5: $1142-1145$.

10. Abdel-Halim, O. B., Ibraheim, Z. Z. and Shiojima, K. (2002). Oleanane triterpenes from Adiantum capillusverenis growing in Egypt. Alexandria Journal of Pharmaceutical Sciences, 16: 87 - 92.

11. Nonato, F. R., Noguiera, T. M., Barros, T. A., Lucchese, A. M., Oliviera, C. E., Santos, R. R., Soares, M. B. and Villarreal, C. F. (2011). Antinociceptive and anti-inflammatory activities of Adiantum latifolium Lam.: evidence for a role of IL-1 $\beta$ inhibition. Journal of Ethnopharcological, 136(3): 518 -524. 